\title{
The Aesthetic Ideas in Furttenbach's Treatise Architectura Civilis (1628)
}

\author{
By Vladimir Mako*
}

\begin{abstract}
Discussion developed in this paper aims to reflect on a particularly important appearance of aesthetic ideas on architecture in the seventeenth century German culture. It seems that in that process one of the leading figures was Joseph Furttenbach, which treatise Architectura Civilis was published in Ulm in 1628. Based on the legacy of the contemporary Italian architecture, it was one of the most important works of this kind written by a German author. The main subject of the treatise-private and public architecture-was discussed in a practical manner, concerning mainly the functional aspects of the art of building. However, in the treatise one can indicate existence of important terms and notions regarding ideas of architectural aesthetics, related to characters and characteristics of the fifteenth, sixteenth and seventeenth century thinking in that field.
\end{abstract}

\section{Introduction}

At the beginning of the sixteenth century, German culture was under the growing influence of the Italian Renaissance. In the field of architecture, Walter Rivius prepared the first Latin edition of the Vitruvius' treatise in 1543, and he translated it into German in 1548. In 1542, the fourth book by Sebastiano Serlio was also translated. Following the first efforts that brought the examples of the Italian Renaissance close to German readers, the treatise Architectura Civilis by Joseph Furttenbach was published in Ulm in 1628. Residing in Italy somewhere between 1607 and 1617, as a young student of commerce, Furttenbach collected a large number of architectural drawings and plans of contemporary buildings, mainly of palaces and villas. During this period, he probably became familiar with Italian architectural literature and went on to meet some of the important architects of that time. A part of this collection, which chiefly consisted of variations of real buildings adapted by Furttenbach to his own understanding of good architecture, was published in his Italian Itinerary in 1627. ${ }^{1}$ A number of collected and adapted examples, mainly found in Genoa, served Furttenbach as a basis for his ideal view on art of building in Architectura Civilis. ${ }^{2}$

Undoubtedly, the sixteenth- and seventeenth-century German ideas on architecture developed under complex cultural influences. In his general comment

\footnotetext{
*Professor, University of Belgrade, Serbia.

1. J. Furttenbach, Newes Itinerarium Italiae (Hildesheim-New York: Georg Olms Verlag, 1971).

2. Furttenbach, Architectura Civilis (Ulm, 1628); for architectural influences on Furttenbach see: H. Rott, Rubens: Palazzi di Genova: Architectural Drawings and Engravings 1 Text and Catalogue, Corpus Rubenianum, Ludwig Burchard, Part XXII, Frans Boudouin and Arnout Balis (Ed. Harvey Miller Publishers, 2002), 81,82.
} 
on German architectural treatises of the period, Kruft attempted to investigate the importance and position of Furttenbach's writings in that process. He emphasized that the ideas developed by Furttenbach were mostly concerned with the exalted use of Greco-Roman orders, missing a serious analytical approach to the basic principles of architectural creativity. ${ }^{3}$ At the same time, he placed Furttenbach among the theoreticians who developed a systematic idea on architecture. ${ }^{4}$ Kruft also drew attention to Furttenbach's use of Italian examples as a model for building practice in Central Europe. Kruft recognized the relationship between Furttenbach and Pierre Le Muet, a French theoretician, in the analytical approach to functional aspects of architecture. ${ }^{5}$ Apparently, being under the influence of Serlio's treatise, Le Muet indirectly transferred some of the Italian Renaissance views to his German colleague. ${ }^{6}$

Another opinion on Furttenbach's treatise and its importance for the development of German architectural theories in the seventeenth century was proposed by Dora Wiebenson, who remarked that his was the first among the works generating from chapters in Italian books regarding civil architecture, such as those by Serlio, Palladio or Scamozi. ${ }^{7}$ An interesting suggestion came from Paul Zucker, ${ }^{8}$ who placed Furttenbach beside Serlio and Sabatini as one of the most important pioneers of stage design. ${ }^{9}$ Similarly, Foramitti pointed out the influence that Giulio Parigi, the eminent Florentine architect, had on developing Furttenbach's interest in stagecraft. ${ }^{10}$ However, Foramitti's analysis did not reveal other possible influences on Furttenbach's attitudes in this field. Above all, Furttenbach seems to have been particularly interested in the parts of Serlio's treatise that were concerned with stagecraft and perspective.

\section{Aesthetic Ideas}

At the beginning of our discussion it is important to emphasize that those esthetic notions and terms which appear in Furttenbach's treatise, are not presented through a systematically developed philosophical theory. They are mainly reflecting on terms and meanings, which become familiar to Furttenbach in his study on Italian renaissance and mannerist architecture. In that context, as in any analysis of aesthetic ideas developed before the appearance of systematic philosophical aesthetic thinking established by Baumgarten , we can extract those

3. H. W. Kruft, A History of Architectural Theories from Vitruvius to the Present (Zwemmer, Princeton Architectural Press, 1994), 166-171.

4. Ibid, 172 .

5. Ibid, 173.

6. D. Wiebenson, Architectural Theory and Practice from Alberti to Ledoux (Architectural Publications Inc., 1982), III-D-2.

7. Ibid, III-D-4.

8. P. Zucker, "The Renaissance Stage. Documents of Serlio, Sabbattini and Furttenbach by Barnard Hewitt," in The Journal of Aesthetics and Art Criticism 18, no. 3 (1960), 398.

9. B. Hewitt, The Renaissance Stage. Documents of Serlio, Sabbattini and Furttenbach (Coral Gables, Fla., University of Miami Press, 1958), 256.

10. H. Foramitti, "Introduction," (Op. Cit.) in Furttenbach Newes Itinerarium Italiae, vi, ix. 
ideas only from the author's broader sense what good architecture and to it related perception and experience could be. However, as those ideas mainly correspond to the general cultural environment and its influence, consequently a comparative analysis of similar contemporary use of aesthetic terms by other authors should be established.

To understand the use of aesthetic terms and positions applied in Furttenbach's treatise, it is important to emphasize that, generally speaking, in the sixteenth and seventeenth century, at least in German speaking region, the way in which a book on architecture was conceptualized defines also the aesthetic concept of the author. Although almost all architectural treatises writhen in these two centuries in German and Dutch language have been calling upon the authority of Vitruvius and, to his work affiliated Italian Renaissance tradition, one can find a substantial difference in the judgment on that which important aspects of good and beautiful architecture should be selected and presented in the work.

We can differentiate two main groups of treatises in regard to the previously mentioned selective approach.

The first group of works has been based on the understanding that the most important aspects of architecture, its beauty and value, derives almost solely from understanding and individual interpretation of the five ancient Greco-Roman orders. This approach belongs to the Mannerist understanding of how tradition should be studied and used in the process of inventing new forms and values in contemporary architecture. From the treatise of Pieter Coecke van Aelst, through the works of Hans Blum, Johannes Vredeman Vriesae, Ihon Shute, Meyer Daniel, Krammer Gabriel, Rotgerus Kaseman, and in the late seventeenth century Johan Hofmann, it is evident that the Vitruvian and Italian Renaissance tradition has been used as an inspiration for the most subjective and fantastic decorative and picturesque inventions in presenting architectural facades and their supporting details. ${ }^{11}$ Highly metaphorical in their approach these inventions still stand without any structural ideas for what the whole of a building should be.

The second group of architectural treatises was conceptualized according to the belief that the art of building involve the structural understanding in which firmness, function, and the overall unification of parts within the whole should be achieved, without the appearance of a good and beautiful building cannot be possible. This understanding was guided by the sense of harmony between all the parts and aspects of a building, which develops far from the notion of picturesque and decorative nature of facades which was emphasized in the works belonging to

11. P. C. Aelst, Die Inventie der Colommen met Haren Coronementen Ende Maten (Antverpia, 1539); H. Blum, Ein Kunstreych Buch von Allerley Antiquiteten, so zum Verstand der Funf Seulen der Architectur Gehorend (Zurich, 1560); I Shute, The First and Chief and Crovndes of Architecture (London, 1563); J. V. Vriesae, Architectura, Oder Bauung der Antiquen aus dem Vitruiuis (Antverpium, 1577); G. Krammer, Schweiff Buchlein Mancherley Schweiff (Collen, 1611); Krammer, Eygentlicher Bericht der Funf Seulen ... (Nurnberg, 1626); Krammer, Architectura von den Funf Seulen Sambt iren Ornamenten und Zierdenals... (Colln, 1646); D. Meyer, J. T. de Bry, J. I. de Bry, Architectura...(Franckfurt am Mayn, 1609); R. Kaseman, Architectura Lehr Seiulen Bochg (Collen, 1615); R. Kassmann, Architectur Nach Antiquitetischer Lehr und Geometrischer Ausstheilung...(Colln, 1653); J. Hofmann, Seulen Buch, Oder Gruendlicher Bericht von den Funf Ordnungen der Architectur Kunst...(Nurnberg, 1672). 
the first group of examples. Behind the notion of rationality regarding construction, building material, measure and modus, all these treatises are developing a psychological sense by which the observer, or user, should experience the technological, social, and aesthetic complexity of architecture. Through the work of Salomon de Bray, Joseph Furttenbach, Georg Andreas Bockler, and in some parts trough the mainly technical work of Johann Wilhelm and Daniel Hartman, we can understand the effort which these authors made to present the theoretical and practical complexity of the art of building. ${ }^{12}$

In that context and by its approach to the essential issues of architecture and building in general, Furttenbach's Architectura Civilis can be defined as pragmatic, emphasizing utility as the primary aspect and the goal in the field of practice. However, besides its main approach, Furttenbach's treatise provides an important perspective on theoretical determination of architectural concerns in general and aesthetic questions in particular. Despite the elementary theoretical sensibility shown in Furttenbach's work, a careful analysis of the text reveals the use of terms and definitions that can lead to a reasonable understanding of the most important aspects of the creative process, and of the making of good and beautiful architecture. Moreover, he also establishes the concept for its aesthetic evaluation.

\section{Notions regarding Aesthetic Experience}

Research of the issues presented above can begin in the parts of Furttenbach's text in which he discusses general categories and principles of experiencing a building. Thus, the important terms and notions were used and developed in the introduction of his treatise.

In his comment on Italian buildings, given on page six of the introductory review of architecture, Furttenbach uses four terms, which in his opinion can define the exceptional value of the examples discussed. He states that some of the buildings are the most precious, richest in art, most sincere and firmest. ${ }^{13}$ These terms are highly significant for this analysis because Furttenbach uses them to define the quality of an architectural work influencing our aesthetic perception and experience.

The term most precious can be read as excellent, and it determines the quality and value of the building material. By using it, Furttenbach highly evaluates the material quality as a component of the total aesthetic value of architecture. It is interesting that for now, in the seventeenth century Germany there is one indicated similar understanding of the value of material as noted in Furttenbach's work. In Wilhelm's treatise from 1649, we can read that a form derives, among other, from

12. S. Bray, Architectura Moderna Ofte Bouwinge van Onsen Tyt (Amstelredam: Danckertsz, Cornelis, 1631); G. A. Bockler, Compendium Architecturae Civilis (Franckfurt am Mayn, 1648); G. A. Bockler, Architectura Civilis, Nova \& Antique, Das ist Von den Funf Saulen yu der Baukunst Gehorig (Franckfurt am Mayn, 1668); J. Wilhelm, Architectura Civilis (Franckfurt am Mayn, 1649); D. Hartmann, Burgerliche Wohnungs Baw-Kunst (Basel, 1672).

13. (Op. Cit.) Furttenbach, Architectura Civilis, vi. 
a good material, probably reflecting on the notion proper in a more complex sense. ${ }^{14}$ Nevertheless, in the context of Furttenbach's general understanding of architecture, the term is probably also used to indicate the mechanical properties of the building material, and not only to highlight its beauty in a pure perceptive sense. Thus, the quality of the building material, also expressed through its market price, would be in accordance with the logic of building construction, not only an element pleasing to the eye.

By using the term richest in art, that is, most skillful, Furttenbach brings on the evaluation of the craftsman's practical skill, by which he implies that the material should be used and worked out in a way adequate to the function it needed to perform. ${ }^{15}$ This way, the artistic skill is equalized with the notion of practical logic that evaluates the quality of the used material and its treatment through the level of its functional optimization.

The same context could apply to the term most sincere, as an aspect that determines two notions mentioned earlier. Thus, the term links to the principle of the ethical ideal, reflecting the harmony between the beautiful, the good and the useful. It brings equilibrium into the relationship between the quality of the building material and the artistic approach and creative intention of the craftsman, while utility reflects the adequate use of material for a proper function. ${ }^{16}$

The term staerckeste - the most firm complements the general definition of the building quality and the properly established building structure; it is probably related to the term firmitas, used by Alberti in his treatise, and with terms venustas and utilitas is reflecting on the Vitruvian tradition when defining good architecture. ${ }^{17}$ Furttenbach's use of the term the most firm, alongside with just analyzed other notions, seems to be of a particular interest in our discussion. Comparing it to the similar term staerck, used by Vriesae in the seventies of the sixteenth century, we can understand the essential difference in meaning by which Furttenbach determined the word firm. ${ }^{18}$ Dutch writer was linking the term firm to the visual effect of the Doric order, guided by decorative and metaphorical purposes, without any regard to the building as a whole, which was the priority in Furttenbach's understanding. Closer to Furttenbach's idea is the context in which the term firm was used by Johan Jacob Bodmer, in the introduction for the second edition of the treatise of Hans Blum, published in $1627 .{ }^{19} \mathrm{He}$ was reflecting on the structural property of the visual whole that can be achieved by using the Doric order which makes the proportion and the relationship between parts of the façade stronger, and by that it gives them a beautiful look and appearance. However, after Furttenbach used the term firm to emphasize the structural property of the whole building, it was repeated, as it seems, only by Bockler in the same context and

14. (Op.Cit.) Wilhelm, Architectura Civilis, 4.

15. (Op.Cit.) Furttenbach, Architectura Civilis, vi.

16. Ibid, vi.

17. L. B. Alberti, On the Art of Building in Ten Books (The MIT Press, Cambridge Mass, 1997), 9.

18. (Op.Cit.) Vriesae, Architectura, Oder Bauung der Antiquen aus dem Vitruuius, 5. 1627), 1 .

19. Blum, V Columae: Das ist, Beschreibung unnd Gebrauch der V Saulen...(Zurich, 
meaning. ${ }^{20}$ For our latter discussion it is important to emphasize that Bockler's treatise in many parts and statements proves similarities with those presented by Furttenbach twenty years before.

The analyzed terms define the objective aspects of the good, beautiful and useful building based on a rational approach to the structure development. In this context, the ideal notion of beauty is secondary; however, one can sense a strong presence of the ethical component in the determination of this important notion. Therefore, the building idea is guided by rational, concrete tasks and goals, while its aesthetical and ethical aspects develop through objective perception and evaluation.

Proceeding with his discussion of aesthetic issues, Furttenbach expands on the given terms on the same page. ${ }^{21}$ In his view, these terms incite high thoughts, diligent beautification, and heroic effectuation, for which Italians are distinguished in town building. Although this is the only passage in the treatise where Furttenbach mentions town planning, he obviously uses these terms to refer to the whole practice of building. It is important for the present analysis that these terms match another group of notions, such as most useful, most charming, and glorious, defining meaning of the entire aesthetic system. Thus, through the notion of most useful, the expression high thoughts determine the categories of the rational approach to building. In this context, diligent beautification leads to the expression of charming as the most appreciated aesthetic notion in the whole system, while the notion of heroic effectuation can be presumed to convey complex social meanings.

A more thorough analysis of the notion heroic effectuation seems to be important for the present discussion, as it is believed to determine the principles of aesthetic appreciation of architectural quality by the society in general. In this context, heroic seems to be the key word, used eleven times in Furttenbach's treatise. ${ }^{22}$ Interestingly, this notion is usually linked with other terms such as firm, rustic, skillfully decorated, suitable for use, valuable and striking. When used alone, heroic defines the general context of a rustic or a monumental effect, in which context it was used once more in the late seventeenth century Germany by Hofmann. ${ }^{23}$ In addition, heroic was used by Furttenbach twice with reference to the effects of color and light provided by architectural elements covered in copper, as an expression close to the notion of monumental. ${ }^{24}$

The possibility that the term heroic determines a higher artistic effect supplementing the rational, functional and structural approaches to building can be found in the description of a courtyard, given through complementary pairs of notions. Describing how the wall was build, Furttenbach composes the first pair using the terms rustic and heroic, and the second pair of expressions, which correspond to the first in meaning, firm in lustrous blocks and artistic stone

20. (Op.Cit.) Bockler, Compendium, 4.

21. (Op.Cit.) Furttenbach, Architectura Civilis, vi.

22. (Op.Cit.) Furttenbach, Architectura Civilis, 2, 3, 5, 6, 8, 19, 26, 33, 40, 50, 62.

23. (Op.Cit.) Hofmann, Seulen Buch, Oder Gruendlicher Bericht von den Funf Ordnungen der Architectur Kunst, ..., 19, 20.

24. (Op.Cit.) Furttenbach, Architectura Civilis, 6, 40. 
carving. ${ }^{25}$ In another example, heroic appearance can be achieved by firm and skillful ornamentation. ${ }^{26}$ These examples can be used to define the essential meaning of the notion of heroic as one of the two segments of a harmoniously projected building. Besides stability and functionality, Furttenbach calls for the existence of an artistic effect (Figure 1).

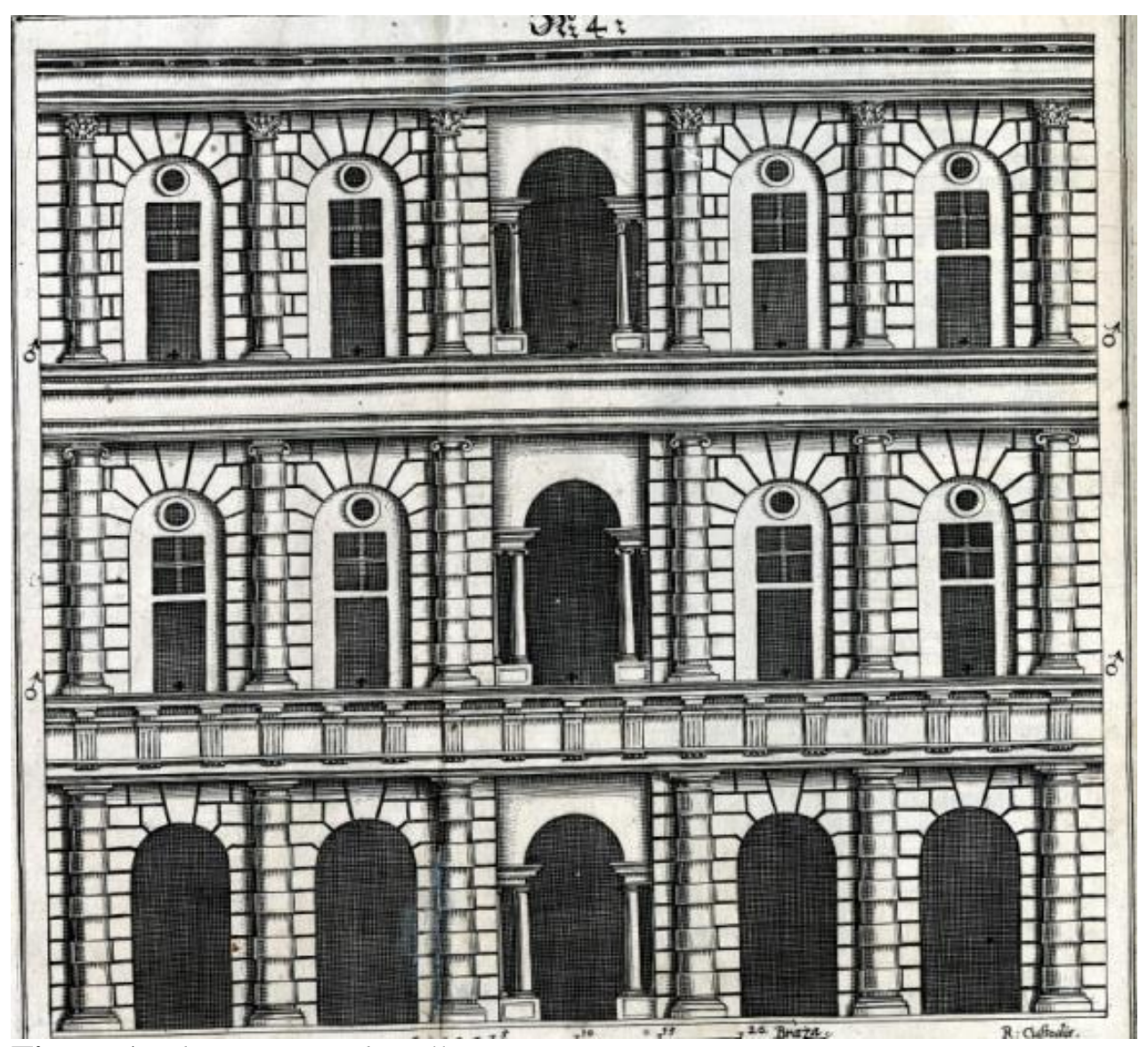

Figure 1. The Courtyard Wall

Source: Architectura Civilis, engraving 4.

Furthermore, the term heroic conveys the meaning of a particular structure consisting of a logical coordination of the inner disposition of rooms and the façade windows, as can be seen in another example. ${ }^{27}$ Along with the previously mentioned notions, such as skillful, artistic, and monumental, the term heroic corresponds to the principle of the logical totality of a building. This Furttenbach's position can be discerned through his use of the term esse in the same example. Generally defining the philosophical essence of a phenomenon, the term esse is used as a determination of the regularity and harmonious unity of parts in a whole. If this unity is achieved, the façade exists; in other words, it has a heroic

25. Ibid, 3.

26. Ibid, 8.

27. Ibid, 19. 
appearance. Thus, the term heroic can be considered as a definition of a perfect visual and functional whole (Figures 2 and 3 ).

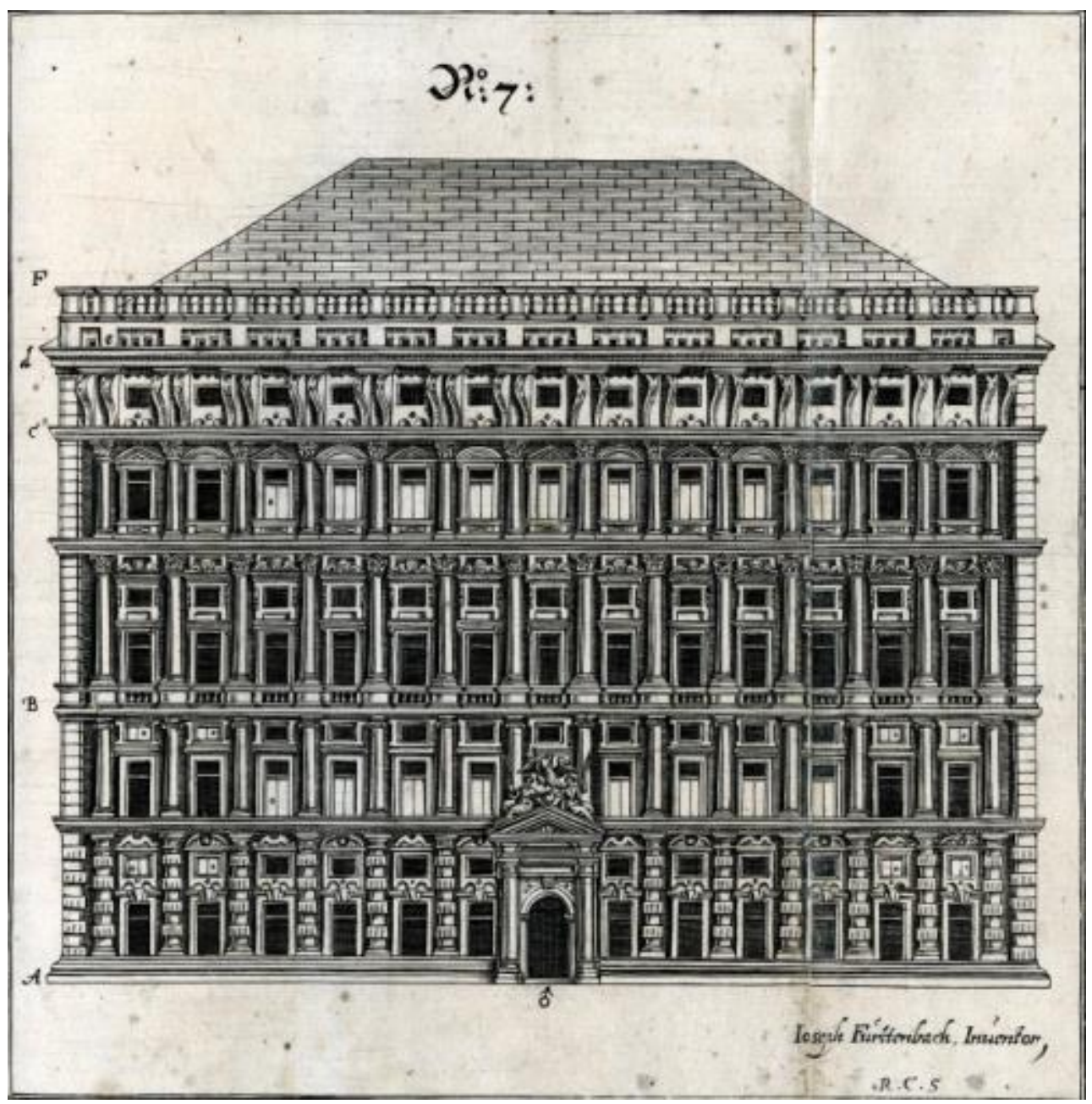

Figure 2. Façade of a Palace

Source: Architectura Civilis, engraving 7. 


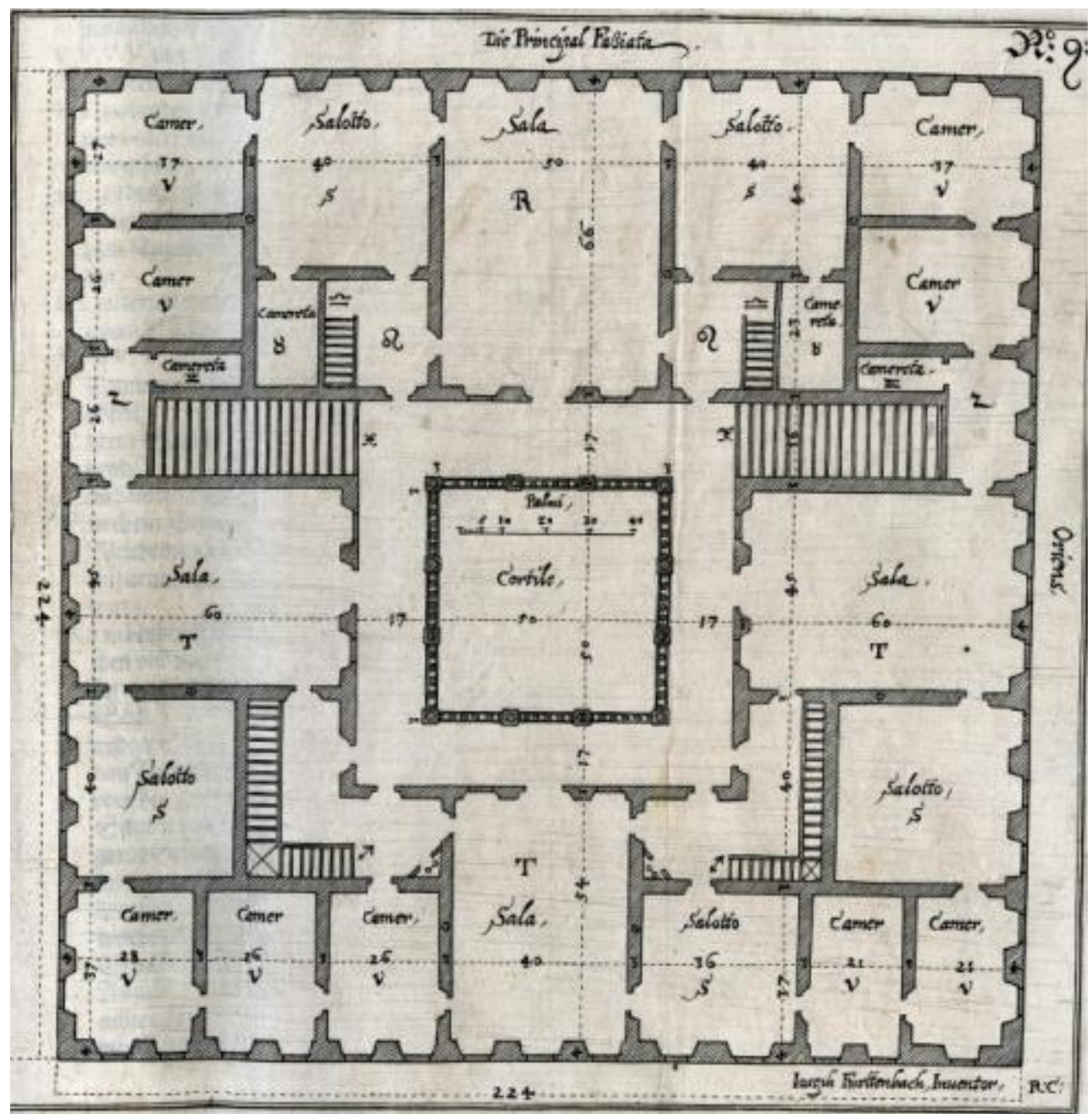

Figure 3. Disposition of Rooms and Windows

Source: Architectura Civilis, engraving 9.

The meaning of heroic help the understanding of Furttenbach's aesthetic attitude when he uses the expression heroic effectuation; in this context, skillful, artistic, monumental and structurally logical piece of architecture achieves glorious appearance. In this way, the notion of effectuation perceptually conveys the values that the notion of heroic comprises. However, it seems that in this context the harmonious relationship between high thoughts and diligent beautification leads to heroic effectuation. Thus established as a category of a building idea in its complete appearance, the expression heroic effectuation can be also thought of as a foundation for general aesthetic evaluation of a work of architecture as glorious, which in this context becomes an example for future generations. In this sense, evaluation of a glorious edifice is established on two principles: first, on its perceptive effect, and second, on the structural and logical unity of all components of which a building consists. Accordingly, it seems that the notion heroic, as established and used by Furttenbach, appears to reflect a 
more complex idea in architecture than it was shown by Kruft. ${ }^{28}$ Although one should acknowledge a certain unsystematic approach in the theoretical meaning of the word, the term heroic can be considered an aesthetic category, mainly when it was used in comparison with other notions.

It is important to emphasize that reflection on this Furttenbach's standpoint regarding the unification of all parts of a building into a visual, functional and meaningful whole, one can sense in a few ideas expressed by Bockler twenty years after. Speaking generally about the essential value of any art, he emphasizes that they exist "trough their meaning", and "that they must appear trough the understanding of that meaning". ${ }^{29}$ Reflecting on the art of building he particularly defines that one of the most important aspects, functionality and proper use, can be obtained through the process of proportioning in which all the inner and external parts should be unified. ${ }^{30}$ In that way, Furttenbach's idea has been confirmed as the essential value of the appearance of a building.

Our understanding of Furttenbach's aesthetic approach to architecture can be completed by the consideration of a term Furttenbach uses twice in his treatise. ${ }^{31}$ Derived from the Italian discretio, in German the term is discreter, which can be translated into English as discreet or discretely, in Robert Klein's interpretation, the importance of this term results from the meaning that reflects man's particular capability for differentiating between notions, similar to the aesthetic evaluation that stands between the senses and the intellect. ${ }^{32}$ Interestingly, Furttenbach uses this term exactly in this sense. First, the term discreet is used to designate a person who makes aesthetic evaluation through the description of architecture that involves particular reflections on the quality and the meticulous approach to the process of evaluation. Further, Furttenbach uses this term to determine the direct evaluation of categories required to achieve an aesthetic effect. This implies that Furttenbach was at least partly familiar with unique Italian sixteenth-century aesthetic terminology, and its proper use. In Italian Renaissance Serlio also uses this term in similar context. In the second book of his treatise on architecture, he says that some decisions regarding the representation of architecture in perspective, or creation of its overall impression should be at the discretion of the man of judgement. ${ }^{33}$ The Furttenbach's conclusion can be supported by the fact that the term discreet has been used in a similar sense before Furttenbach by Vriesae, who was particularly well educated in Italian Renaissance terminology, and who understood the delicate finesse of that notion and its meaning. ${ }^{34}$

28. (Op.Cit.) Kruft, A History of Architectural Theories from Vitruvius to the Present, 173.

29. (Op.Cit.) Bockler, Compendium Architecturae Civilis, 1.

30. Ibid, 4.

31. (Op.Cit.) Furttenbach, Architectura Civilis, vi, xi.

32. R. Klein, "Judgment and Taste in Cinquecento Art Theory," in Form and Meaning. Essays on the Renaissance and Modern Art (New York: The Viking Press: 1979), 161-169.

33. S. Serlio, On Architecture Book II (18v) (New Havan and London: Yale University Press, 1996), 37.

34. (Op.Cit.) Vriesae, Architectura, Oder Bauung der Antiquen aus dem Vitruuius, 8. 


\section{Aesthetic Principles of Good Architecture}

Continuing with general remarks on architecture, Furttenbach introduces more terms to define the quality of a building, ${ }^{35}$ giving a succession of terms that indicate the existence of a more sophisticated level of aesthetic quality, such as agreeable, pleasant, ornament and solicitous. These terms usually supplement expressions such as well-established and artistically arranged as the primal categories of valuable architecture. At the end of the same paragraph, Furttenbach summarizes the previous discussion, emphasizing that a work of architecture as a whole and in detail should be firm, strong, healthy, complete and attractive. Defined in this way, these categories of evaluation of an architectural work seem to follow the Vitruvian-Renaissance tradition. Nevertheless, their universality and lasting value can be confirmed by the author's statement that it should be expected that such an established structure would be used by successors in the time to come and be useful to them. In this sense, Furttenbach establishes the principles of good architecture without discussing architectural orders, which he calls the arrangement of beautifying with columns in five ways. ${ }^{36}$ In his direct use of the terms agreeable, scale, and structure, as three principles on which every building should be based, Furttenbach is closer to Alberti's definition of architectural structure than to the later discussion on Greco-Roman architectural orders. ${ }^{37}$

Further, in the description of one of the palaces, Furttenbach analyzes in detail what good architecture should comprise. ${ }^{38}$ From his textual description we can summarize six developed principles as following points: 1 . firm construction; 2. regular rhythm of openings as a prerequisite for correct ornamentation; 3. good vertical communication via stairways; 4 . the existence of a grand hall as the social center for a broader society; 5. well-proportionate, symmetrically and linearly arranged rooms, establishing inner prospects and, perceived from outside, a regular disposition of windows; 6 . good floor communications and a number of functions providing pleasant and relaxing atmosphere.

This description may best define Furttenbach's attitude to the aesthetic principles of architecture. Mainly, the principles are related to structural and functional elements. However, the points 2, 4, and 5 emphasize important components that supplement pure construction and function, particularly the principle presented in point 4 . The idea that the palace should have a hall as the centre of social life broadens the context in which the term function is used elsewhere. The function of the palace is not only to provide content and pleasantness to its residents, but it is also highly recommended to have a social role as the centre of political and social meetings. For Furttenbach, architecture also expresses socio-political aspects of functionality.

On the other hand, the principles expressed in points 2 and 5 could be linked to define a rule for achieving a complete and regular building structure. In this

35. (Op.Cit.) Furttenbach, Architectura Civilis, vii.

36. Ibid, xii; (Op.Cit.) Kruft, A History of Architectural Theories from Vitruvius to the Present, 173.

37. (Op.Cit.) Furttenbach, Architectura Civilis, 9.

38. Ibid, 8. 
context, a symmetrical and well-proportioned inner structure is necessarily reflected on the façade in the regular disposition of doors and windows. ${ }^{39}$ This complex structural concept can be found in Palladio's attitude to architecture defined by the term commodo, as a category that refers to regular vertical and horizontal disposition of openings. ${ }^{40}$ Such a disposition of building components was considered a prerequisite for beauty and elegance, ${ }^{41}$ similar to the idea expressed by Furttenbach.

\section{Aesthetic Notions of Individuality in Architectural Design}

Generally, Furttenbach considers architectural structure as a complex system that requires a particularly serious approach to design. It seems that in Furttenbach's opinion this complexity brings about different architectural expressions, which he terms different sentences. ${ }^{42}$ It is interesting that Furttenbach compares these sentences with different general impressions that people have when they observe and describe architectural works. This means that he accepts the existence of different personal attitudes to aesthetic values of architectural works and consequently, the subjective aesthetic evaluation as a legitimate act. On a few occasions, Furttenbach emphasizes the opinion that a personal position of an architect is acceptable even in the choice of the decorative elements necessary for beautifying particular parts of architecture. ${ }^{43} \mathrm{He}$ remarks that there is only a strict requirement for establishing a regular structure of a building, but all other activities undertaken to provide an impression of beauty can be left to each architect's personal satisfaction. ${ }^{44}$ Hence, Furttenbach can be presumed to understand that beauty rests on individual and subjective evaluation although it must answer to building logic through applying reasonable decisions. It seems that in this respect, Furttenbach follows certain Italian sixteenth-century ideas, such as Castiglione's, to whom differentiation of manners corresponds to individual temperaments. ${ }^{45} \mathrm{In}$ addition, Furttenbach, influenced by the thought of previous centuries, believes that man's ability to create beauty is God's gift of innate reasoning. ${ }^{46}$ Therefore, the creative power of beauty consists of two components: logic and individual attitude; in its essence, it is sublime, because it is a gift from the divine Creator.

These Furttenbach's statements are generally following the main ideas on individual ingenuity developed in the sixteenth and seventeenth German writers on architecture. This refers particularly to those authors which attitude towards art of building has been developed through the primacy of the research on five GrecoRoman orders. Almost all of them implied the idea that on the base of regular

39. Furtenbah also makes this evaluation on p. 19 of the quoted work.

40. A. Palladio, The Four Books on Architecture (Cambridge Mass. \& London: The MIT Press, 1997), 60.

41. Ibid, 78 .

42. (Op.Cit.) Furttenbach, Architectura Civilis, viii.

43. Ibid, 27.

44. Ibid, 30.

45. B. Castiglione, The Book of the Courtier (London: J.M. Dent \& Sons, Ltd., 1944), 164.

46. (Op.Cit.) Furttenbach, Architectura Civilis, 36. 
proportional rules exposed by these orders, the contemporary architect should investigate the possibility of inventing and applying a new concept, or manner, which is adequate to the spirit of the epoch, and the conditions given by the climate and national differences. This generally known attitude, accepted also by Furttenbach, was probably the reason why he avoided any discussion on orders in his treatise. He obviously thought that nothing new in this sense can be expressed, and therefore concentrated on aesthetic aspects regarding the structural logic of architecture, which in his opinion, has not been discussed in detail before.

Developing further ideas related to creativity, Furttenbach comments on the logic of what he calls the modus of thinking. He considers that a process through which a personal statement on architecture originates from another personal statement can be misleading in the apprehension of the true values of a building. However, this can be superseded by following the steps of an accurate designing procedure. In this context, Furttenbach emphasizes the importance of model making which provides "a complete, suitable and artistic composition and preparation". 47 However, it seems that the notion of the genuinely permanent values in architecture is not rooted in an idealistic philosophy, but rests on the material, functional, structural and skillful components of building. In Furttenbach's opinion, such values can be learned by researching the existing examples of good architecture, and from interviews with distinguished architects. The pragmatic nature of direct studying and following the existing experience is of a higher value than speculative training in idealistic and theoretical concepts. Practice leads towards the development of experience and thus generates new ideas and solutions. ${ }^{48}$ However, the process cannot be seen as unsophisticated automatism because only the "spirit of free will and patience" will produce a good, creative architect. ${ }^{49}$ Patient research and talent led by the logic of practice are the components necessary for high-quality building. This is the main logic underlying Furttenbach's entire system of thinking.

Besides the analyzed aesthetic aspects that are important for our understanding of Furttenbach's opinion on what good architecture can be, the treatise also contains a few interesting statements regarding particular functional issues. Thus, Furttenbach seems to maintain that the differences in living habits among nations play an important role in establishing the proper function of residential architecture. In describing one of the projects for residential purposes, he says that in the process of its design he has mixed "Italian with German habits and customs". ${ }^{50}$ By doing so, Furttenbach establishes the Italian model as having general importance for the conceptualization of good architecture, and yet shows full understanding of the particularities of lifestyle and climate in Germany that necessitate transformations of this highly desirable ideal (Figure 4).

\section{Ibid, $\mathrm{x}$.}

48. Ibid, 48.

49. Ibid.

50. Ibid; (Op.Cit.) Kruft, A History of Architectural Theories from Vitruvius to the Present, 173. 


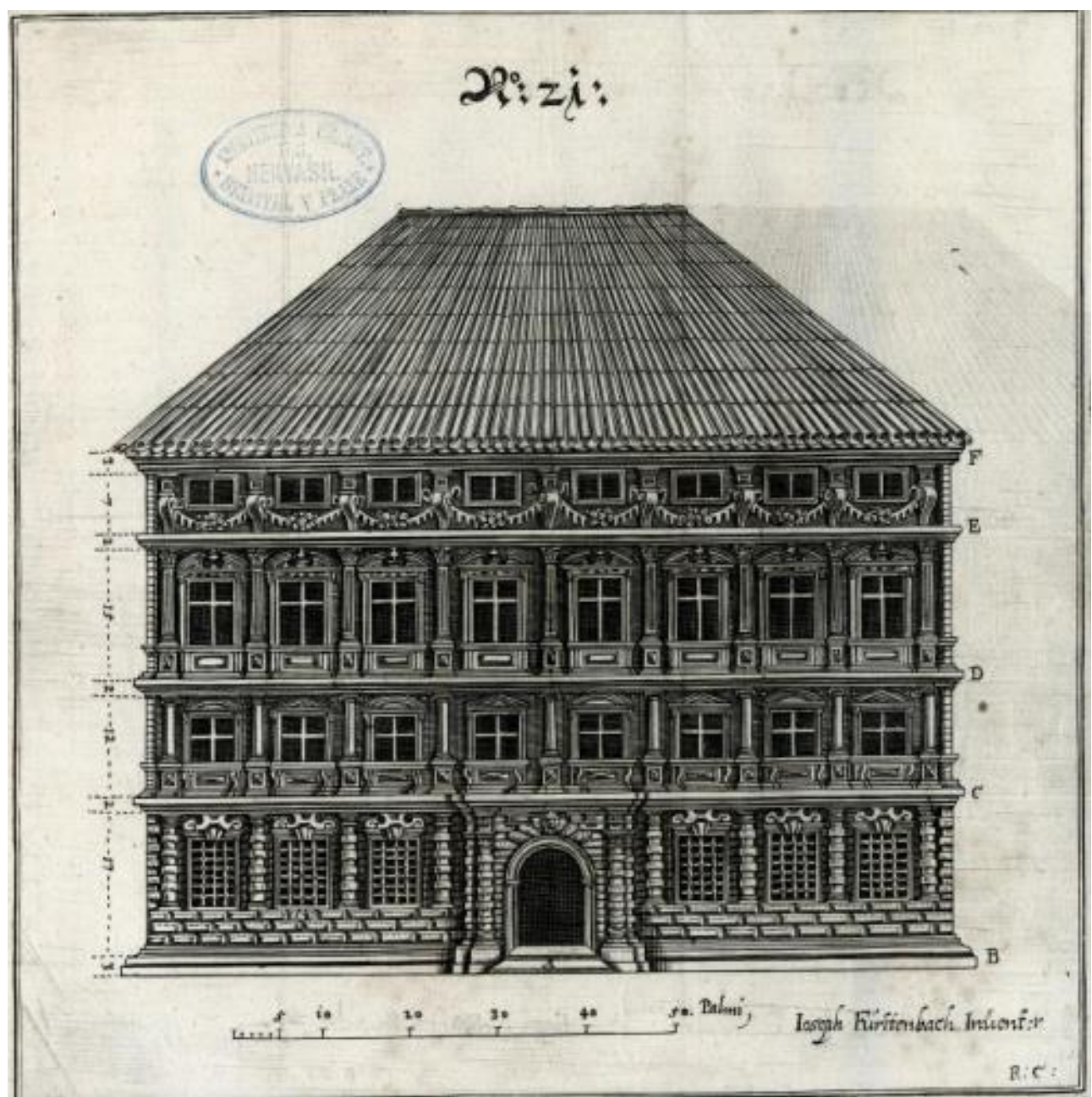

Figure 4. Façade of a Palace Adapted to German Customs

Source: Architectura Civilis, engraving 21.

That this approach is deliberate is proved by several similar comments in the text, which indicate that the necessity of transformation of the Italian architectural model is caused by the "manner of the country", in other words, by its habits and customs. ${ }^{51}$ These comments confirm Furttenbach's essentially rational approach to building. Despite his fascination with Italian architectural rules and models, Furttenbach's structural logic reflects the real habits and climatic particularities, which prevail over the unquestioning pursuit of ideals. In this way, he follows almost in detail the idea which has been already defined by de Bray in his treatise on modern architecture. ${ }^{52}$

For our understanding of all important aesthetic aspects developed by Furttenbach, we should analyze another interesting example. Continuing with his comments on the functional solutions of buildings, Furttenbach pays particular attention to the character of the person for whom the building is designed. ${ }^{53}$ By

51. (Op.Cit.) Furttenbach, Architectura Civilis, 49, 50, 56.

52. (Op.Cit.) Bray, Architectura Moderna ofte Bouwinge van Onsen Tyt, 11.

53. (Op.Cit.) Furttenbach, Architectura Civilis, 49. 
doing so, he implicates the important influences that the personal demands of the investor, his character, and profession - that is, the psychological aspects - have in the process of design. The importance of this issue derives from a similar context in which de Bray was analyzing a few projects of architectural portals made by Hendrick de Keyser. In these comments, de Bray was emphasizing how the architectural function has been reflected through the character of the applied design, and how according to that quality, the architect managed to become diligent and attentive in art. ${ }^{54}$ In this context, Furttenbach's idea reached a higher level of understanding what importance the characterization of architecture can bring into the designing process.

The notion of the beautiful is not extensively discussed in the treatise; however, Furttenbach's views can be found in a few passages. Usually, the beautiful is linked to the fascination with the diversity of charming effects. ${ }^{55}$ It seems that for Furttenbach the feeling or experience of a beautiful site results from the variety and multitude of its contents, curiosities and surprises. However, the treatise also offers views of beauty that are more complex. For Furttenbach, an outstandingly beautiful hall is the one that was structuralized by elegant modulation, by bringing its breadth, length and height into proportional harmony. ${ }^{56}$ This is close to the opinion expressed by Palladio although there is no certainty of its origin in Furttenbach's work. However, Furttenbach's idea which links beauty of a building and structural proportions, was again expressed by Bockler, but now more explicitly as one of the essential requirements in the art of building $^{57}$ (Figure 5).

54. Ibid,14ff.

55. Ibid, $3,32$.

56. Ibid, 4. From Furttenbach's accompanying designs, it can be concluded that the proportions of large halls vary from case to case, and thereby build ratios such as 9:14, 1:2, 9:12:17. Smaller halls are usually proportioned as cubes $1: 1: 1$. It is particularly obvious in Engravings Nos. 3, 9, and 10.

57. (Op.Cit.) Bockler, Compendium Architecturae Civilis, 5. 


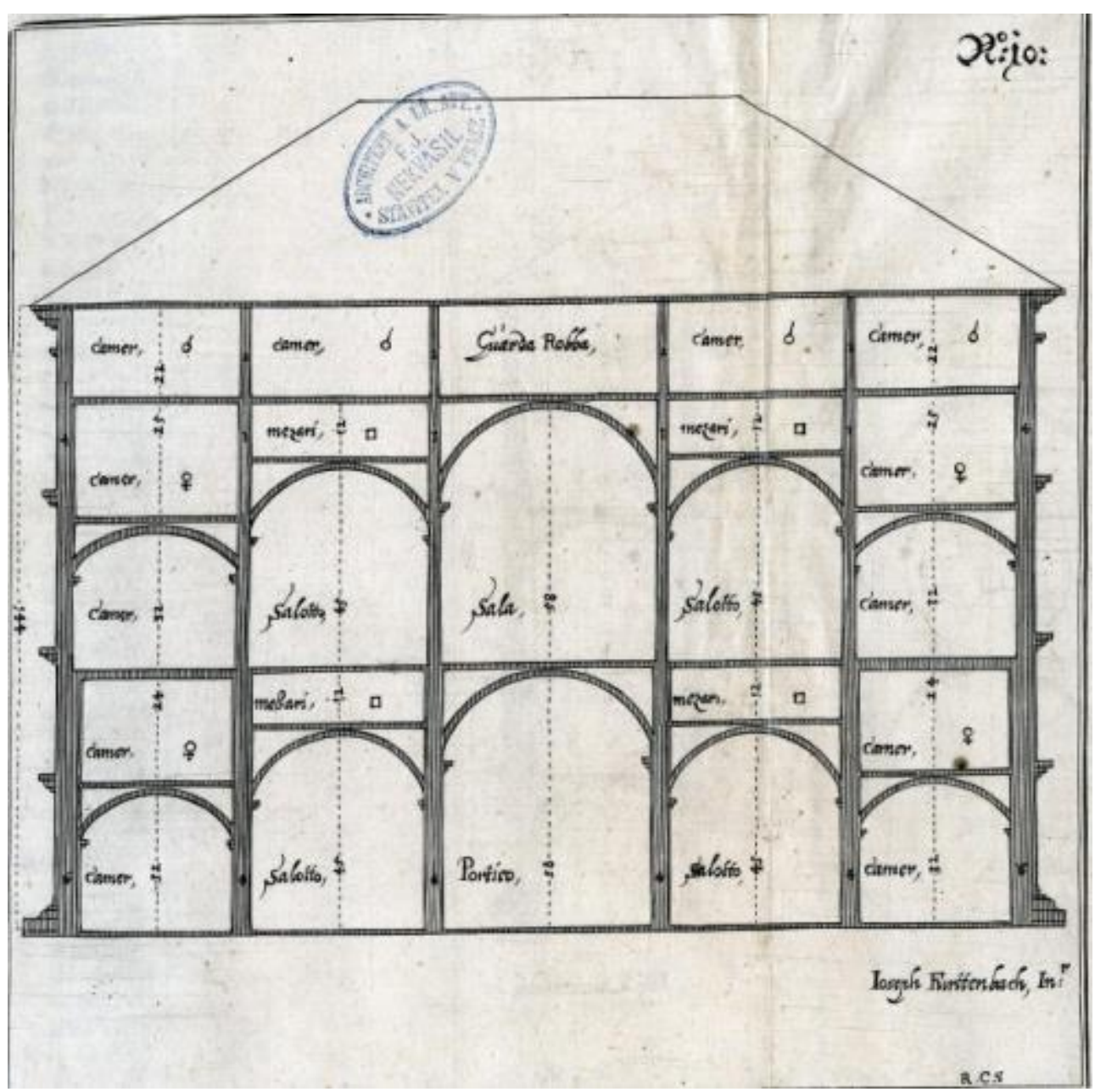

Figure 5. The Cross Section showing the Proportions of the Inner Structure

Source: Architectura Civilis, engraving 10.

Additionally, a building achieves a beautiful appearance if its rooms are comfortable, and according to that, even the feelings of pleasantness, joy or amusement, more or less individual, can be considered as sources of beauty. ${ }^{58}$ Thus, the structures providing the feeling of leisure and cheerfulness are beautiful. ${ }^{59}$ The sense of beauty also comes from the skill and complexity of performing a work of art, the brightness of light, ${ }^{60}$ the sheen of the materials used and their variety. ${ }^{61}$ This is similar to a theater play, which is beautiful when it pleases the spectator's sight and hearing, providing a complete sense of charm. ${ }^{62}$ Beautiful work should always create a pleasant feeling even after it has been observed for a long time. In order to produce this effect, the performance skill

58. (Op.Cit.) Furttenbach, Architectura Civilis, 9, 42.

59. Ibid, 26.

60. Ibid, 28.

61. Ibid, 32.

62. Ibid, 30. 
should be complemented with various materials and colors, because a "longer exposure to them... does not provoke a boring impression". 63

However, it seems that sometimes his attitude to the subject of beauty leads to a more complex notion of levels of its perception. In a few examples, Furttenbach emphasizes that the garden statues "do not only help to decorate...but they also generate other pleasant artistic thoughts, with which the spirit can be joyful..."64; sometimes this joy is so strong that the observer "forgets himself completely" ${ }^{65}$ In this way, Furttenbach indicates the psychological power of beauty, especially when he uses the expression stirring beauty, ${ }^{66}$ explaining how the space of the sepultura santa of the church of St. Lorenzo in Genoa produces the effect of monumentality and perspective guidance for observers. ${ }^{67}$ As in other case studies and examples, it is considered necessary for a visual mark to be seen at a distant point in order to build such an effect. ${ }^{68}$

Further development of the idea that beauty affects the observer psychologically can be seen in Furttenbach's explanation of the notion of atmosphere as an important aspect of perception of a piece of work. Darkness of a grotto is necessary because then its content can be experienced "with greater passion and deeper purpose". ${ }^{69}$ Yet, whatever the level of complexity that the expression of beauty can reach, it is always related to the sense of usefulness. When Furttenbach speaks of the process of contemplation of beauty of a building or its part, he usually complements it with a description of its well-established function. ${ }^{70} \mathrm{~A}$ useful building is a source of joy and happiness and therefore it supplements the feeling of beauty, creating a complete aesthetic sensation.

\section{Conclusions}

It seems that our discussion indicates that in his treatise Furttenbach established important unity between aspects regarding the quality of architecture and to it related human emotional experience, both creative and perceptual. Moreover, one can think of an appearance of a more or less systematically developed aesthetic concept in its essential sense. However, our analysis of Furttenbach's use of potential aesthetic terms and their meanings regarding the quality of architectural expression shows that his understanding of esthetic perception and experience develops more in the realm of practice than as a philosophical speculation. In that sense, his interpretation of emotional responds to architecture reflects more on basic psychological principles of human behavior and satisfaction, than on profound spiritual contemplation on deeper cultural

63. Ibid, 62 .

64. Ibid, 32 .

65. Ibid, 35 .

66. Ibid, 63.

67. The original representation of the space is given in Engraving No. 15. In: (Op.Cit.) Furttenbach, Newes Itinerarium Italiae.

68. (Op.Cit.) Furttenbach, Architectura Civilis, 33.

69. Ibid, 37.

70. Ibid, 9, 26, 59 . 
meanings. Nevertheless, the way in which Furttenbach emphasizes the necessity of establishing German manner in architecture out from Italian models, indicates his standpoint that aesthetic expression can be formed by a deeper cultural need and influence.

Research and scientific examination of Joseph Furttenbach's use of aesthetic notions in his treatise Architectura Civilis would not be so significant in itself that it not influenced the spreading of Italian architecture and individual aesthetic attitudes over German lands in the seventeenth and eighteenth centuries. In this process, his treatise occupies an especially important place because it is a work that not only informed the German reader about a new scope of Italian art of architecture, but it also contained and conveyed the ideas arising from the relationship between subjective and universal creative thinking, principles of good architecture, and aesthetics.

In this sense, Furttenbach's treatise can be considered as the germ of the further development of German theoretical treatises on architecture, which tended to follow the most eminent minds of the rest of Europe, and at the same time to distinguish the specific features and needs of their own region. The study of ideas, designs, theoretical statements, and aesthetical considerations collected in Architectura Civilis can be regarded to have lasting significance for understanding how the thoughts on architecture and the principles of its materialization were shaped at the time it was created, as well as in the centuries that followed. The analysis of Furttenbach's theoretical assumptions, many of which are yet unexplored, suggests that his treatise on architecture aroused special interest for the classical in architecture in German scholars of a later date.

\section{Bibliography}

Aelst, P. C. Die Inventie der Colommen met Haren Coronementen Ende Maten. [The Investment of the Columns with Her Coronements and Sizes.] Antverpia, 1539.

Alberti, L. B. On the Art of Building in Ten Books. The MIT Press, Cambridge Mass, 1997, 9.

Blum, H. Ein Kunstreych Buch von Allerley Antiquiteten, so zum Verstand der Funf Seulen der Architectur Gehorend. [An Art-Literary Book of All-Antiquities, thus Belonging to the Mind of 5 Pillars of the Architecture.] Zurich, 1560.

Blum, H. V Columae: Das ist, Beschreibung und Gebrauch der V Saulen, ... [V Columae: That's the Description and Use of the V Columns,...] Zurich, 1627.

Bockler, G. A. Compendium Architecturae Civilis. [Brief Civil Architecture.] Franckfurt am Mayn, 1648.

Bockler, G. A. Architectura Civilis, Nova \& Antique, Das ist Von den Funf Saulen yu der Baukunst Gehorig. [Civi Architecture, New \& Old, This is heard from the Five Sauls and the Architecture.] Frankfurt am Mayn, 1668.

Bray, S. Architectura Moderna ofte Bouwinge van Onsen Tyt. Amstelredam: Danckertsz, Cornelis, 1631.

Castiglione, B. The Book of the Courtier. London: J.M. Dent \& Sons, Ltd., 1944.

Furttenbach, J. Architectura Civilis. [Civil Architecture.] Ulm, 1628.

Furttenbach, J. Newes Itinerarium Italiae. [News from Italian Itinerary]. Hildesheim-New York: Georg Olms Verlag, 1971. 
Hartmann, D. Burgerliche Wohnungs Baw-Kunst. [Bourgeois Housing Baw Art.] Basel, 1672 .

Hewitt, B. The Renaissance Stage. Documents of Serlio, Sabbattini and Furttenbach. Coral Gables, Fla., University of Miami Press, 1958.

Hofmann, J. Seulen Buch, Oder Gruendlicher Bericht von den Funf Ordnungen der Architectur Kunst,...[Book or thorough Review of the 5 Orders of Architectural Art.] Nurnberg, 1672.

Kaseman, R. Architectura Lehr Seiulen Bochg, Collen, 1615.

Kassmann, R. Architectur Nach Antiquitetischer Lehr und Geometrischer Ausstheilung, Colln, 1653.

Klein, R. "Judgment and Taste in Cinquecento Art Theory." In Form and Meaning: Essays on the Renaissance and Modern Art. New York: The Viking Press: 1979.

Krammer, G. Schweiff Buchlein Mancherley Schweiff, Collen, 1611.

Krammer, G. Eygentlicher Bericht der funf Seulen ..., Nurnberg, 1626.

Krammer, G. Architectura von den Funf Seulen sambt iren Ornamenten und Zierdenals. Colln, 1646.

Kruft, H. W. A History of Architectural Theories from Vitruvius to the Present. Zwemmer, Princeton Architectural Press, 1994.

Meyer, D., de Bry, J. T., de Bry, J. I. Architectura... [Architecture...] Franckfurt am Mayn, 1609.

Palladio, A. The Four Books on Architecture. Cambridge Mass. \& London: The MIT Press, 1997.

Rott, H. Rubens: Palazzi di Genova: Architectural Drawings and Engravings 1 Text and Catalogue, Corpus Rubenianum, Ludwig Burchard, Part XXII, Frans Boudouin and Arnout Balis, Ed. Harvey Miller Publishers, 2002.

Serlio, S. On Architecture. Book II (18v). New Havan and London: Yale University Press, 1996.

Shute, I. The First and Chief and Crovndes of Architecture, London, 1563.

Vriesae, J. V. Architectura, Oder Bauung der Antiquen aus dem Vitruuius. [Architecture, or Construction of the Antiquities from the Vitruvius.] Antverpium, 1577.

Wiebenson, D. Architectural Theory and Practice from Alberti to Ledoux, Architectural Publications Inc, 1982.

Wilhelm, J. Architectura Civilis. [Civil Architecture.] Franckfurt am Mayn, 1649.

Zucker, P. "The Renaissance Stage. Documents of Serlio, Sabbattini and Furttenbach by Barnard Hewitt." In The Journal of Aesthetics and Art Criticism 18, no. 3 (1960). 
